\title{
HIV Alters Plasma and M. tuberculosis-induced Cytokine Production in Patients with Tuberculosis
}

\author{
S. SUBRAMANYAM, L.E. HANNA, P. VENKATESAN, K. SANKARAN, \\ P.R. NARAYANAN, and S. SWAMINATHAN
}

\begin{abstract}
To test the hypothesis that HIV infection brings about an alteration in the immune response to tuberculosis (TB), mycobacterial antigen-induced production and plasma levels of the inflammatory cytokine interferon- $\gamma$ (IFN- $\gamma$ ) and its regulatory cytokines interleukin-12 (IL-12), IL-18, and IL-10 were determined in patients infected dually with HIV and TB and compared with individuals with either disease and with healthy controls. Peripheral blood mononuclear cells (PBMCs) of TB patients with HIV infection produced lesser amounts of IFN- $\gamma$ and IL-12 compared with TB patients without HIV infection after in vitro stimulation with mycobacterial antigens. There was no difference in antigen-induced IL-18 production in TB patients with or without HIV infection. The in vivo cytokine pattern did not correlate with that seen in vitro. Higher levels of IFN- $\gamma$, IL-12, and IL-18 were detected in the plasma of TB patients infected with HIV compared with TB patients without HIV infection. The presence of significantly higher plasma levels of proinflammatory cytokines suggests a greater degree of immune activation in individuals with HIV and TB, particularly those with low CD4 counts. In vitro IL-10 production by HIV-positive TB patients was similar to that of the HIV-negative TB group and higher than in HIV-positive individuals without TB, but the plasma levels were similar. HIV infection downregulates the in vitro Th1 cytokine response to $T B$ and simultaneously increases systemic levels of these cytokines.
\end{abstract}

\section{INTRODUCTION}

$\mathbf{T}$ UUBERCUlOSIS (TB) CONTINUES TO BE the most prevalent cause of death from an infectious agent globally, and its interaction with HIV is having devastating effects. ${ }^{(1)} \mathrm{HIV}$ infection has emerged as by far the most important of all the predisposing factors for the development of $\mathrm{TB}^{(2)}$ (primary or reactivation) ${ }^{(3,4)}$ and $\mathrm{TB}$ is often the sentinel illness of HIV infection. ${ }^{(5)}$ TB causes worsening of HIV disease status, increases viral replication, decreases immunity, and hastens the onset of AIDS. $\left.{ }^{6}\right)$

The pattern of cytokines produced by $\mathrm{T}$ lymphocytes plays a central role in the susceptibility to TB. Activation of Th1 lymphocytes, interferon- $\gamma(\mathrm{IFN}-\gamma)$ production, and macrophage activation are crucial in the defense against mycobacteria. ${ }^{(7)}$ On the other hand, Th2 cell activation and increased interleukin-4 (IL-4) production have been associated with poor clinical outcome after treatment. ${ }^{(8)}$ HIV infection is associated with a profound deregulation of the immune system and alterations in the cytokine profile. ${ }^{(9)}$ The present study was carried out to test the hypothesis that HIV infection brings about an alteration in the host immune response to TB. To this end, in vivo levels of the proinflammatory cytokine IFN- $\gamma$ and its regulatory cytokines (IL-12, IL-18, and IL-10) in plasma, as well as mycobacterial antigen-induced production of these cytokines by peripheral blood mononuclear cells (PBMCs) in vitro, were investigated in TB patients with and without HIV infection.

\section{MATERIALS AND METHODS}

\section{Study population}

Patients suspected of having HIV infection or TB were investigated at the Tuberculosis Research Centre, Chennai. The diagnosis of TB was based on sputum smear examination for acid-fast bacilli and confirmed by culture for Mycobacterium tuberculosis. HIV infection was diagnosed using two rapid tests (HIV Tridot, J. Mitra, New Delhi, India, and CombAids, Span

Tuberculosis Research Centre, Mayor V R Ramanathan Road, Chetput, Chennai-600031, India. 
Diagnostics, Surat, India), and a positive result was confirmed by an ELISA test (Enzaids, Span Diagnostics).

The study population comprised four groups of individuals: (1) 29 HIV-seropositive patients with active TB (22 males and 7 females, age range 21-52 years, mean age 35 years), (2) 21 HIV-seronegative patients with TB (15 males and 6 females, age range 18-70 years, mean age 42 years), (3) 26 HIV-seropositive patients without active TB (19 males and 7 females, age range 19-50 years, mean age 33 years), and (4) 22 healthy controls (11 males and 11 females, age range $21-48$ years, mean age 32 years) who were laboratory workers in the Tuberculosis Research Centre.

All HIV-positive patients tested positive for HIV-1, and 3 also had HIV-2 co-infection. Among the TB patients, 1 had pleural effusion, and all the rest had sputum-positive pulmonary TB. The group comprising HIV patients without TB was highly diverse. The majority of the individuals in this group had other opportunistic infections, such as pneumonia, diarrhea, or central nervous system (CNS) infections, and were being treated as inpatients in the Government Hospital for Thoracic Medicine, Tambaram, Chennai at the time of the study. One person had hepatitis B co-infection, 1 was being treated for sexually transmitted disease, and 4 were asymptomatic. The most common risk factor for HIV infection in the study population was heterosexual promiscuity. None of the patients were receiving antituberculosis or antiretroviral therapy at the time of intake into the study.

\section{Cytokine assay}

PBMCs were obtained by density gradient centrifugation on Ficoll diatrizoate. The cells were washed with RPMI 1640 medium (Bio-Whittaker, Walkersville, MD), and their viability count was ascertained by the trypan blue dye exclusion method. PBMCs were cultured in 24-well tissue culture plates (Falcon, Lincoln Park, NJ) at a concentration of $2 \times 10^{6}$ cells/well in a volume of $1 \mathrm{ml}$ RPMI 1640 medium supplemented with $1 \mathrm{mM}$ L-glutamine, $80 \mu \mathrm{g} / \mathrm{ml}$ gentamicin, $25 \mathrm{mM}$ HEPES, and $10 \%$ fetal bovine serum (FBS). The cells were stimulated in vitro with two mycobacterial antigens and a mitogen. The antigens used were purified protein derivative (PPD) (Conaught, Willowdale, Ontario, Canada) and heat-killed M. tuberculosis H37Rv (Hk-M.tb.) (prepared in our laboratory). The mitogen used was phorbol myristate acetate (PMA) (Calbiochem, San Diego, CA) in combination with ionomycin (Calbiochem). PPD was used at a concentration of $10 \mu \mathrm{g} / \mathrm{ml}, \mathrm{Hk}-\mathrm{M} . \mathrm{tb}$. at $10 \mu \mathrm{g} / \mathrm{ml}$, PMA at $50 \mathrm{ng} / \mathrm{ml}$, and ionomycin at $1 \mu \mathrm{g} / \mathrm{ml}$. The cell culture supernatants were collected after $24 \mathrm{~h}$ for estimation of IL-10, IL-12, and IL-18 and after $72 \mathrm{~h}$ for estimation of IFN- $\gamma$. Concentrations of the antigens and mitogen used and the duration of culture were found previously to give optimal cytokine responses in our laboratory. The cell culture supernatants were stored at $-70^{\circ} \mathrm{C}$ until use. Cytokines were measured by capture ELISA using kits purchased from Immunotech (Coulter, Hialeah, FL). To rule out technical error, about $10 \%$ of all the samples were run in duplicate, and the paired results were compared for concurrence.

\section{Immunophenotyping}

The monoclonal antibodies (mAbs) used for immunophenotyping were anti-CD14, anti-CD45, anti-CD3, anti-CD4, and
anti-CD8. Irrelevant isotope-matched antibodies (mouse IgG1 and mouse $\operatorname{IgG} 2 \mathrm{a}$ ) were included as controls for nonspecific immunofluorescence. All the mAbs were directly conjugated with either fluorescein isothiocyanate (FITC) or phycoerythrin (PE) and were purchased from Becton Dickinson Immunocytometry (Mountain View, CA).

Lymphocyte subpopulations were analyzed in whole blood by dual-color flow cytometry using the standard staining protocol. The cells were analyzed on a FACSort flow cytometer (Becton Dickinson) using CellQuest software. Data were collected per 10,000 cells for each tube and analyzed as dot-plots.

\section{Statistical analysis}

All results are expressed as mean $\pm \mathrm{SE}$. Wherever necessary, $\log$ transformation was used to stabilize variance. Comparison of the means between any two groups was performed using unpaired $t$-test. The four groups were compared simultaneously using analysis of variance (ANOVA). Tukey's multiple comparison test was also used to classify the groups. The significance was fixed at the $5 \%$ level.

\section{RESULTS}

Routine hematologic and biochemical tests as well CD4 ${ }^{+}$ cell counts were performed for all study subjects. HIV-infected patients had significantly lower $\mathrm{CD}^{+}{ }^{+}$cell counts than HIVnegative patients $(284 \pm 56$ cells $/ \mu 1$ vs. $758 \pm 53$ cells $/ \mu 1, p<$ 0.001 ) (Table 1). Based on the CD4 counts, both groups of HIV patients (categories 1 and 3) were further divided into two subgroups, those having CD 4 counts $>200$ cells $/ \mu 1$ and those with CD4 counts $<200$ cells/ $\mu 1$. Each of these subgroups had more or less equal numbers of patients. Thus, there were six groups (I, II, III, IV, V, VI).

\section{IFN- $\gamma$ in plasma and in supernatants of mycobacterial antigen-stimulated PBMCs}

Antigen-induced IFN- $\gamma$ production was measured in the supernatants of PBMCs cultured with PPD or Hk-M.tb. for $72 \mathrm{~h}$. Mean IFN- $\gamma$ levels in mycobacterial antigen-stimulatedcell cultures for TB patients were 2-fold higher than the corresponding values for healthy controls (Table 1). A trend toward a decline in IFN- $\gamma$ production was observed in patients co-infected with HIV. Very small amounts of IFN- $\gamma$ were measured in culture supernatants of HIV patients without active TB. Although plasma IFN- $\gamma$ levels were higher in patients with either TB or HIV than in healthy controls, this increase did not reach statistical significance. Among HIV patients with advanced disease, low CD4 counts $(<200$ cells $/ \mu \mathrm{l})$, and active TB, there was a significant increase in the amount of circulating IFN- $\gamma(p<$ $0.05)$. On the other hand, in HIV patients with moderate CD4 counts (200-500 cells/ $\mu \mathrm{l})$ and active TB, circulating IFN- $\gamma$ levels were not elevated to the same extent.

\section{IL-12 in plasma and in supernatants of in vitro stimulated PBMCs}

PBMCs of TB patients produced significantly higher amounts of IL-12 in response to in vitro stimulation with PPD 
Table 1. IFN- $\gamma$ Levels in Plasma and Culture Supernatants of IN Vitro Stimulated PBMCs

\begin{tabular}{|c|c|c|c|c|c|}
\hline Group & Subjects & $\begin{array}{l}\text { CD4 counts } \\
(\text { cells/ } / \mathrm{l})\end{array}$ & $\begin{array}{c}\text { PPD-stimulated } \\
\text { PBMC }(\mathrm{pg} / \mathrm{ml})\end{array}$ & $\begin{array}{c}\text { Hk-M.tb.- } \\
\text { stimulated } \\
\text { PBMC }(\mathrm{pg} / \mathrm{ml})\end{array}$ & $\begin{array}{l}\text { Plasma } \\
(\mathrm{pg} / \mathrm{ml})\end{array}$ \\
\hline${ }^{\text {I }}(n=14)$ & $\begin{array}{l}\mathrm{HIV}+\mathrm{TB}+ \\
\quad(\mathrm{CD} 4>200)\end{array}$ & $284 \pm 20^{\mathrm{a}}$ & $280.8 \pm 124.0$ & $333.2 \pm 128.8$ & $31.0 \pm 10.1$ \\
\hline II $\quad(n=15)$ & $\begin{array}{l}\mathrm{HIV}+\mathrm{TB}+ \\
\quad(\mathrm{CD} 4<200)\end{array}$ & $89 \pm 16$ & $409.4 \pm 275.0$ & $170.5 \pm 87.3$ & $91.6 \pm 25.1^{*}$ \\
\hline $\begin{array}{l}\text { III } \\
\quad(n=21)\end{array}$ & $\mathrm{TB}+$ & $609 \pm 56$ & $730.2 \pm 184.5$ & $799.1 \pm 438.5$ & $23.6 \pm 5.1$ \\
\hline $\begin{array}{l}\text { IV } \\
(n=14)\end{array}$ & $\begin{array}{l}\mathrm{HIV}+\mathrm{TB}- \\
\quad(\mathrm{CD} 4>200)\end{array}$ & $432 \pm 76$ & $1.8 \pm 0.4$ & $15.2 \pm 6.8$ & $36.0 \pm 32.2$ \\
\hline $\mathrm{V}(n=12)$ & $\begin{array}{l}\mathrm{HIV}+\mathrm{TB}- \\
\quad(\mathrm{CD} 4<200)\end{array}$ & $63 \pm 10$ & $4.1 \pm 2.0$ & $5.4 \pm 2.4$ & $39.7 \pm 8.2$ \\
\hline $\begin{array}{l}\mathrm{VI} \\
\qquad(n=22)\end{array}$ & $\begin{array}{l}\text { Healthy } \\
\text { controls }\end{array}$ & $758 \pm 53$ & $323.3 \pm 130.4$ & $279.5 \pm 135.7$ & $7.5 \pm 1.5$ \\
\hline
\end{tabular}

${ }^{a}$ Mean \pm SE.

$* p<0.05$ compared with all other groups.

compared with healthy controls $(p<0.005)$ (Table 2$)$. HIV coinfection in TB patients resulted in a significant decrease in IL12 production in response to PPD $(p<0.005)$. Though HkM.tb.-induced IL-12 production was also lower in HIV-positive TB patients compared with TB patients without HIV infection, the difference between the groups was not statistically significant. PBMCs of HIV-positive individuals without TB produced very low amounts of IL-12 in response to mycobacterial antigens in vitro. Plasma IL-12p70 levels did not differ significantly in any of the study groups. However, a trend toward an increase in circulating IL-12 levels was observed in HIV-infected TB patients, particularly the group with low CD4 counts, compared with those with TB alone.

\section{IL-18 in plasma and in supernatants of in vitro stimulated PBMCs}

No significant difference was observed in IL-18 production in PPD and Hk-M.tb.-stimulated cultures of PBMCs from healthy controls and from patients (Table 3 ). Mean IL-18 concentrations in cell culture supernatants of TB patients were similar irrespective of the presence or absence of HIV infection. PBMCs of HIV-positive individuals without TB produced very low amounts of IL-18. Plasma IL-18 levels were significantly higher in TB patients than in healthy controls $(p<0.001)$. Patients with both HIV and TB (irrespective of CD4 counts) had significantly higher IL-18 levels than the other four groups $(p<$ $0.01)$.

\section{IL-10 in plasma and in supernatants of in vitro stimulated PBMCs}

PPD-induced IL-10 production was highly variable and not significantly different in any of the study groups. However, HkM.tb. induced significantly higher production of IL-10 in individuals with TB compared with healthy controls $(p<0.001)$ (Table 4). Both among HIV patients with moderate CD4 counts $(200-500$ cells $/ \mu 1)$ and those with low CD4 counts $(<200$

Table 2. IL-2 Levels in Plasma and Culture Supernatants of $I_{N}$ Vitro Stimulated PBMCs

\begin{tabular}{|c|c|c|c|c|}
\hline Group & Subjects & $\begin{array}{c}\text { PPD-stimulated } \\
\text { PBMC }(\mathrm{pg} / \mathrm{ml})\end{array}$ & $\begin{array}{c}\text { Hk-M.tb.- } \\
\text { stimulated } \\
\text { PBMC }(\mathrm{pg} / \mathrm{ml})\end{array}$ & $\begin{array}{l}\text { Plasma } \\
(\mathrm{pg} / \mathrm{ml})\end{array}$ \\
\hline I & $\begin{array}{l}\mathrm{HIV}+\mathrm{TB}+ \\
\quad(\mathrm{CD} 4>200)\end{array}$ & $9.1 \pm 2.9^{\mathrm{a}, *}$ & $17.0 \pm 5.3$ & $15.4 \pm 4.2$ \\
\hline II & $\begin{array}{l}\mathrm{HIV}+\mathrm{TB}+ \\
\quad(\mathrm{CD} 4<200)\end{array}$ & $4.7 \pm 1.4^{*}$ & $13.6 \pm 4.4$ & $41.1 \pm 14.5$ \\
\hline III & $\mathrm{TB}+$ & $16.9 \pm 3.0 * *$ & $39.2 \pm 15.0$ & $9.2 \pm 2.1$ \\
\hline IV & $\begin{array}{l}\mathrm{HIV}+\mathrm{TB}- \\
\quad(\mathrm{CD} 4>200)\end{array}$ & $5.9 \pm 2.2$ & $17.6 \pm 1.5$ & $5.2 \pm 1.9$ \\
\hline V & $\begin{array}{l}\mathrm{HIV}+\mathrm{TB}- \\
\quad(\mathrm{CD} 4<200)\end{array}$ & $13.6 \pm 1.2$ & $3.5 \pm 0.1$ & $17.8 \pm 3.6$ \\
\hline VI & $\begin{array}{l}\text { Healthy } \\
\text { controls }\end{array}$ & $3.6 \pm 0.7$ & $30.3 \pm 13.0$ & $8.0 \pm 1.8$ \\
\hline
\end{tabular}

${ }^{\mathrm{a}}$ Mean $\pm \mathrm{SE}$.

$* p<0.005$ compared with group III.

$* * p<0.005$ compared with group VI. 
Table 3. IL-18 Levels in Plasma and Culture Supernatants of $I_{N} V_{\text {Itro }}$ Stimulated PBMCs

\begin{tabular}{|c|c|c|c|c|}
\hline Group & Subjects & $\begin{array}{c}\text { PPD-stimulated } \\
\text { PBMC }(\mathrm{pg} / \mathrm{ml})\end{array}$ & $\begin{array}{c}\text { Hk-M.tb.- } \\
\text { stimulated } \\
\text { PBMC }(\mathrm{pg} / \mathrm{ml})\end{array}$ & $\begin{array}{l}\text { Plasma } \\
(\mathrm{pg} / \mathrm{ml})\end{array}$ \\
\hline I & $\begin{array}{l}\mathrm{HIV}+\mathrm{TB}+ \\
\quad(\mathrm{CD} 4>200)\end{array}$ & $138.3 \pm 92.7^{\mathrm{a}}$ & $204.4 \pm 124.5$ & $1191.6 \pm 139.1 *$ \\
\hline II & $\begin{array}{l}\mathrm{HIV}+\mathrm{TB}+ \\
\quad(\mathrm{CD} 4<200)\end{array}$ & $78.3 \pm 55.5$ & $106.4 \pm 20.9$ & $1167.8 \pm 150.5^{*}$ \\
\hline III & $\mathrm{TB}+$ & $87.5 \pm 26.2$ & $236.6 \pm 49.3$ & $767.8 \pm 240.0 * * * * * *$ \\
\hline IV & $\begin{array}{l}\mathrm{HIV}+\mathrm{TB}- \\
\quad(\mathrm{CD} 4>200)\end{array}$ & $5.5 \pm 5.1$ & $5.5 \pm 2.9$ & $635.5 \pm 79.7 * * * * * *$ \\
\hline V & $\begin{array}{l}\mathrm{HIV}+\mathrm{TB}- \\
\quad(\mathrm{CD} 4<200)\end{array}$ & $11.2 \pm 0.1$ & $12.5 \pm 4.7$ & $790.6 \pm 64.5 * *, * * *$ \\
\hline VI & $\begin{array}{l}\text { Healthy } \\
\text { controls }\end{array}$ & $92.2 \pm 25.2$ & $99.1 \pm 31.3$ & $333.7 \pm 63.5^{* * * *, * * *}$ \\
\hline
\end{tabular}

${ }^{\mathrm{a}} \mathrm{Mean} \pm \mathrm{SE}$.

$* p<0.01$ compared with group III.

$* * p<0.05$ compared with group I.

$* * * p<0.05$ compared with group II.

cells/ $\mu 1)$, patients with TB produced significantly higher amounts of IL-10 in response to Hk-M.tb. compared with those without active TB $(p<0.05)$. No statistically significant differences were observed in plasma IL-10 levels in any of the study groups.

\section{DISCUSSION}

To our knowledge, this is the first study to simultaneously evaluate both mycobacterial antigen-induced cytokine production by PBMCs in vitro and their plasma concentrations in patients with both HIV and TB. Many investigators have evaluated cytokine levels either in plasma or in culture supernatants of PBMCs obtained from patients with HIV or TB, ${ }^{(10-12)}$ but only a few have measured IFN- $\gamma$ levels in patients with dual infection. ${ }^{(13,14)}$ We found that in TB patients with HIV infec- tion, in vitro IFN- $\gamma$ production in response to mycobacterial antigens was variable but tended to be lower than in TB patients without HIV infection. Elliott et al. ${ }^{(14)}$ also reported profoundly impaired IFN- $\gamma$ responses to mycobacterial antigens in HIV patients with TB. Depression of in vitro immune responses in patients with dual infection could be the result of either the loss of antigen-specific cells or their reduced response to stimulation with mycobacterial antigens. In contrast, plasma levels of IFN- $\gamma$ were significantly higher in HIV-infected TB patients with low CD4 counts $(<200$ cells $/ \mu \mathrm{l})$ than in HIV-negative TB patients as well as in HIV-positive TB patients with higher $\mathrm{CD}^{+}{ }^{+}$cell counts, indicating that immune activation is maximal in patients with advanced HIV infection and TB.

These observations indicate that plasma cytokine levels do not reflect $M$. tuberculosis-induced cytokine production by PBMCs, and vice versa. A similar finding has been reported recently in TB patients by Vankayalapati et al., ${ }^{(15)}$ suggesting that

Table 4. IL-10 Levels in Plasma and Culture Supernatants of $I_{N}$ Vitro Stimulated PBMCs

\begin{tabular}{|c|c|c|c|c|}
\hline Group & Subjects & $\begin{array}{c}\text { PPD-stimulated } \\
\text { PBMC }(\mathrm{pg} / \mathrm{ml})\end{array}$ & $\begin{array}{c}\text { Hk-M.tb.- } \\
\text { stimulated } \\
\text { PBMC }(\mathrm{pg} / \mathrm{ml})\end{array}$ & $\begin{array}{l}\text { Plasma } \\
(\mathrm{pg} / \mathrm{ml})\end{array}$ \\
\hline I & $\begin{array}{l}\mathrm{HIV}+\mathrm{TB}+ \\
\quad(\mathrm{CD} 4>200)\end{array}$ & $446.7 \pm 112.7^{\mathrm{a}}$ & $4525.2 \pm 482.9^{*}$ & $6.3 \pm 2.0$ \\
\hline II & $\begin{array}{l}\mathrm{HIV}+\mathrm{TB}+ \\
\quad(\mathrm{CD} 4<200)\end{array}$ & $378.1 \pm 281.4$ & $3028.9 \pm 500.6^{* *}$ & $17.8 \pm 3.9$ \\
\hline III & $\mathrm{TB}+$ & $393.7 \pm 165.2$ & $3792.1 \pm 319.3 * * *$ & $7.8 \pm 3.3$ \\
\hline IV & $\begin{array}{l}\mathrm{HIV}+\mathrm{TB}- \\
\quad(\mathrm{CD} 4>200)\end{array}$ & $140.0 \pm 50.6$ & $1258.0 \pm 513.6$ & $24.0 \pm 5.2$ \\
\hline $\mathrm{V}$ & $\begin{array}{l}\mathrm{HIV}+\mathrm{TB}- \\
\quad(\mathrm{CD} 4<200)\end{array}$ & $53.3 \pm 42.8$ & $741.7 \pm 234.6$ & $16.7 \pm 5.3$ \\
\hline VI & $\begin{array}{l}\text { Healthy } \\
\text { controls }\end{array}$ & $225.8 \pm 84.1$ & $1683.1 \pm 351.3$ & $24.8 \pm 2.9$ \\
\hline
\end{tabular}

${ }^{\mathrm{a}}$ Mean $\pm \mathrm{SE}$.

$* p<0.05$ compared with group IV.

$* * p<0.05$ compared with group $\mathrm{V}$.

$* * * p<0.05$ compared with group VI. 
serum cytokine levels do not parallel $M$. tuberculosis-induced cytokine production by PBMCs. It has been demonstrated that $\mathrm{T}$ cells and macrophages at the site of disease in TB have the capacity to produce IFN- $\gamma$, and increased local vascular permeability is likely to favor diffusion of cytokines into the bloodstream. ${ }^{(15)}$ It is, therefore, speculated that elevated plasma levels of IFN- $\gamma$ and its regulatory cytokines in patients with HIV and TB are caused by their leakage from tissues into the circulation.

Production of IFN- $\gamma$ by T cells depends on the synergistic effects of the monokines IL-12 and IL-18, both of which are believed to be necessary for full expression of Th1 responses. ${ }^{(16-18)}$ IL-12 is produced by various cell types, such as phagocytic cells, dendritic cells (DC), and B lymphocytes, and induces the production of IFN- $\gamma$ from T cells and natural killer (NK) cells after binding to its own receptor. ${ }^{(19)}$ Like IL-12, IL18 is synthesized by various cell types and synergizes with IL12 in the enhancement of NK cell cytotoxicity and of T cell proliferation, as well as the induction of IFN- $\gamma$ production by T cells, particularly CD4 ${ }^{+}$cells. ${ }^{(19)}$ In our study, lower amounts of IL-12 were produced by PBMCs of patients with HIV and TB compared with those with TB alone in response to both the mycobacterial antigens used. The difference was found to be statistically significant, however, only with PPD and not with Hk-M.tb., probably because of the purified and specific nature of PPD compared with the crude Hk-M.tb. antigen. There was no significant difference in plasma levels of IL-12 between TB patients with and without HIV co-infection, although there was a trend toward an increase in IL-12 levels in patients with severe immunodeficiency. In contrast, although IL-18 production by PBMCs was not significantly different between the HIVpositive and HIV-negative TB patients, plasma IL-18 levels were higher in individuals with dual infection compared with those with TB alone. Mayanja-Kizza et al. ${ }^{(20)}$ studied in vivo levels of IL-12 and IL-18 in HIV-infected and uninfected patients with TB and reported findings similar to ours.

IL-10, a cytokine produced by macrophages, is a potent immunosuppressive factor. Some intracellular pathogens specifically target macrophages for infection and use IL-10 to dampen the host immune response and stall their elimination from the host. ${ }^{(21)}$ We found that although in vitro production of IL-10 in response to PPD was not significantly different in any of the study groups, Hk-M.tb. induced significantly higher production of IL-10 in HIV patients with TB than in HIV patients without TB. Patients with HIV infection have been shown to have higher IL-10 production in response to Mycobacterium avium antigen. ${ }^{(22)}$ Plasma IL-10 levels in the different study groups varied considerably and did not show statistical significance, although the lowest levels were seen in HIV-uninfected TB patients. In the literature, increased levels of plasma IL-10 have been associated with adult HIV disease progression, with the highest levels in patients with the most advanced disease. ${ }^{(23)}$ Surprisingly, high levels of plasma IL-10 were detected in the healthy controls included in our study. A probable explanation for this phenomenon could be the high prevalence of and consequently high exposure to parasitic, helminthic, and other tropical diseases. Lukwiya et al. ${ }^{(24)}$ reported an increased frequency of IL-10-producing cells in both HIV-infected Africans and uninfected Africans compared with Italian controls. Yet another study described high levels of plasma IL-10 in healthy contacts of TB patients. ${ }^{(25)}$ Because the healthy controls included in our study were laboratory workers from a TB hospital who had prolonged exposure to $\mathrm{TB}$, their immune response could be similar to that of contacts of TB patients. However, this finding needs to be confirmed in larger groups of individuals with and without contact with TB. In addition, the role of IL-10 in modifying disease progression in HIV-infected patients in India needs further study.

In summary, we have demonstrated significant immune activation, as seen by high plasma IFN- $\gamma$, IL-12, and IL-18, in patients dually infected with TB and HIV compared with those with either infection alone. The Th1 arm of the immune system appears to be maximally stimulated, particularly in individuals with advanced HIV disease, and this is likely to be a double-edged sword. It is, therefore, unlikely that further stimulation of T lymphocytes will be beneficial, whereas the effect of antagonizing these cytokines is still unknown. Although the findings of our study reveal an active inflammatory response in vivo, a downregulation of the in vitro immune response was observed in patients with TB and HIV.

The present study has a few limitations. These include a relatively small sample size in each study group, heterogeneity of the HIV-positive TB-negative group, and lack of information on the PPD status of the study subjects. Although it is not possible to draw definitive conclusions at this stage on the significance of circulating cytokines as a predictor of activation state, our study provides preliminary evidence on the high levels of circulating Th1 cytokines in patients with advanced HIV disease and TB. Further research is needed into the mechanisms of cytokine dysregulation in HIV-infected patients and also the impact of treatment of both HIV and TB on cytokine production. Plasma levels of IFN- $\gamma$ and IL-18 or their surrogate markers need to be studied longitudinally in order to correlate them with disease outcome.

\section{ACKNOWLEDGMENTS}

We thank Dr. J.L. Fahey and the UCLA Fogarty Postdoctoral AIDS International Training and Research Program, TW 00013, for their helpful discussions and encouragement. Dr. Soumya Swaminathan and Dr. Sudha Subramanyam participated in the UCLA Fogarty Postdoctoral AIDS International Training and Research Program, Los Angeles, CA. We are grateful to patients and volunteers for consenting to provide blood for the study and to the staff of the bacteriology division for performing the bacteriologic investigations. Financial supported was provided by the Indian Council of Medical Research.

\section{REFERENCES}

1. ORME, I.M. (2000). Tuberculosis: recent progress in basic immunity and vaccine development. Kekkaku 75, 97-101.

2. HAVLIR, D.V., and BARNES, P.F. (1999). Tuberculosis in patients with human immunodeficiency virus infection. N. Engl. J. Med. 340, 367-373.

3. DALEY, C.L., SMALL, P.M., SCHECTER, G.F., SCHOOLNIK, G.K., McADAM, R.A., JACOBS, W.R., Jr., and HOPEWELL, P.C. (1992). An outbreak of tuberculosis with accelerated pro- 
gression among persons infected with the human immunodeficiency virus: an analysis using restriction-fragment-length polymorphisms. N. Engl. J. Med. 326, 231-235.

4. SELWYN, P.A., HARTEL, D., LEWIS, V.A., SCHOENBAUM, E.E., VERMUND, S.H., KLEIN, R.S., WALKER, A.T., and FRIEDLAND, G.H. (1989). A prospective study of the risk of tuberculosis among intravenous drug users with human immunodeficiency virus infection. N. Engl. J. Med. 320, 545-550.

5. CENTERS FOR DISEASE CONTROL. (1993). The 1993 revised classification system for HIV infection and expanded surveillance case definition for AIDS among adolescents and adults. MMWR 41, 1-19.

6. GOLETTI, D., WEISSMAN, D., JACKSON, R.W., GRAHAM, N.M., VLAHOV, D., KLEIN, R.S., MUNSIFF, S.S., ORTONA, L., CAUDA, R., and FAUCI, A.S. (1996). Effect of Mycobacterium tuberculosis on HIV replication: role of immune activation. J. Immunol. 157, 1271-1276.

7. BARNES, P.F., and MODLIN, R.J. (1996). Human cellular responses to Mycobacterium tuberculosis. Curr. Top. Microbiol. Immunol. 215, 197-219.

8. LEINHARDT, C., AZZURRI, A., AMEDEI, A., FIELDING, K., SILLAH, J., SOW, O.Y., BAH, B., BENAGIANO, M., DIALLO, A., MANETTI, R., MANNEH, K., GUSTAFSON, P., BENNETT, S., D'ELIOS, M.M., McADAM, K., and DEL PRETE, G. (2002). Active tuberculosis in Africa is associated with reduced Th1 and increased Th2 activity in vivo. Eur. J. Immunol. 32, 1605-1613.

9. AGARWAL, S.K., SINGH, A., ANURADHA, S., SINGH, N.P., SOKHI, J., and BAVEJA, U.K. (2001). Cytokine profile in human immunodeficiency virus positive patients with and without tuberculosis. J. Assoc. Phys. India 49, 799-802.

10. SODHI, A., GONG, J., SILVA, C., QIAN, D., and BARNES, P.F. (1997). Clinical correlates of interferon gamma in patients with tuberculosis. Clin. Infect. Dis. 25, 617-620.

11. FENG, C.G., BEAN, A.G.D., HOOI, H., BRISCOE, H., and BRITTON, W.J. (1999). Increase in gamma interferon secreting CD8 ${ }^{+}$ as well as $\mathrm{CD}^{+}{ }^{+} \mathrm{T}$ cells in lungs following aerosol infection with Mycobacterium tuberculosis. Infect. Immun. 67, 3242-3247.

12. FAHEY, J.L. (1998). Cytokines, plasma immune activation markers, and clinically relevant surrogate markers in human immunodeficiency virus infection: minireview. Clin. Diag. Lab. Immunol. 5, 597-603.

13. HODSON, W.S., LUZZE, H., HURST, T.J., QUIGLEY, M.A., KYOSIIMIRE, J., NAMUJJU, P.B., JOHNSON, J.L., KALEEBU, P., OKEWARA, A., and ELLIOTT, A.M. (2001). HIV-1-related pleural tuberculosis: elevated production of IFN-gamma, but failure of immunity to Mycobacterium tuberculosis. AIDS 15, 467-475.

14. ELLIOTT, A.M., HURST, T.J., BALYEKU, M.N., QUIGLEY, M.A., KALEEBU, P., FRENCH, N., BIRYAHWAHO, B., WHITWORTH, J.A., DOCKRELL, H.M., and HAYES, R.J. (1999). The immune response to Mycobacterium tuberculosis in HIV-infected and uninfected adults in Uganda: application of a whole blood cytokine assay in an epidemiological study. Int. J. Tuberc. Lung Dis. 3, 239-247.

15. VANKAYALAPATI, R., WIZEL, B., WEIS, S.E., KLUCAR, P., SHAMS, H., SAMTEN, B., and BARNES, P.F. (2003). Serum cytokine concentrations do not parallel Mycobacterium tuberculosisinduced cytokine production in patients with tuberculosis. Clin. Infect. Dis. 36, 24-29.

16. KOHNO, K., KATAOKA, J., OHTSUKI, T., SUEMOTO, Y., OKAMOTO, I., USUI, M., IKEDA, M., and KURIMOTO, M. (1997). IFN- $\gamma$-inducing factor (IGIF) is a costimulatory factor on the activation of Th1 but not Th2 cells and exerts its effects independently of IL-12. J. Immunol. 158, 1541-1550.

17. AHN, H.J., MARUO, S., TOMURA, M., MU, J., HAMAOKA, T., NAKANISHI, K., CLARK, S., KURIMOTO, M., OKAMURA, H., and FUJIWARA, H. (1997). A mechanism underlying synergy between IL-12 and IFN- $\gamma$-inducing factor in enhanced production of IFN- $\gamma$. J. Immunol. 159, 2125-2131.

18. YOSHIMOTO, T., TAKEDA, K., TANAKA, T., OHKUSU, K., KASHIWAMURA, S., OKAMURA, H., AKIRA, S., and NAKANISHI, K. (1998). IL-12 up-regulates IL-18 receptor expression on $\mathrm{T}$ cells, Th1 cells, and B cells: synergism with IL-18 for IFN- $\gamma$ production. J. Immunol. 161, 3400-3407.

19. AIROLDI, I., GRI, G., MARSHALL, J.D., CORCIONE, A., FACCHETTI, P., GUGLIELMINO, R., TRINCHIERI, G., and PISTOIA, V. (2000). Expression and function of IL-12 and IL-18 receptors on human tonsillar B cells. J. Immunol. 165, 6880-6888.

20. MAYANJA-KIZZA, H., JOHNSON, J.L., HIRSCH, C.S., PETERS, P., SUREWICZ, K., WU, M., NALUGWA, G., MUBIRU, F., LUZZE, H., WAJJA, A., AUNG, H., ELLNER, J.J., WHALEN, C., and TOOSSI, Z. (2001). Macrophage-activating cytokines in human immunodeficiency virus type 1-infected and uninfected patients with pulmonary tuberculosis. J. Infect. Dis. 183, 1805-1809.

21. REDPATH, S., GHAZZAL, P., and GASCOIGNE, N.R. (2001). Hijacking and exploitation of IL-10 by intracellular pathogens. Trends Microbiol. 9, 86-92.

22. MULlER, F., AUKRUST, P., LIEN, E., HAUG, C.J., and FROLAND, S.S. (1998). Enhanced interleukin-10 production in response to Mycobacterium avium products in mononuclear cells from patients with human immunodeficiency virus infection. J. Infect. Dis. 177, 586-594.

23. SRIKANTH, P., CASTILLO, R.C., SRIDHARAN, G., JOHN, T.J., ZACHARIAH, A., MATHAI, D., and SCHWARTZ, D.H. (2000). Increase in plasma IL-10 levels and rapid loss of $\mathrm{CD}^{+} \mathrm{T}$ cells among HIV-infected individuals in South India. Int. J. STD AIDS 11, 49-51

24. LUKWIYAL, M., RIZZARDINI, G., TRABATTONI, D., PICONI, S., SARESELLA, M., DECLICH, S., FOSSATI, S., and CLERICI, M. (2001). Evaluation of immune activation in HIV-infected and uninfected African individuals by single-cell analysis of cytokine production. J. Acquir. Immune Defic. Syndr. 28, 429-436.

25. OLOBO, J.O., GELETU, M., DEMISSIE, A., EGUALE, T., HIWOT, K., ADERAYE, G., and BRITTON, S. (2001). Circulating TNF-alpha, TGF-beta and IL-10 in tuberculosis patients and healthy contacts. Scand. J. Immunol. 53, 85-91.

Address reprint requests or correspondence to: Dr. Soumya Swaminathan Deputy Director Division of HIV/AIDS Tuberculosis Research Centre Mayor V R Ramanathan Road Chetput, Chennai-600 031

India

$+91-44-28362432-35$

+91-44-28362528

E-mail: doctorsoumya@yahoo.com

Received 10 June 2003/Accepted 23 September 2003 